\title{
Meeting the needs of the customers
}

'The services of the public library are provided on the basis of equality of access for all, regardless of age, race, sex, religion, nationality, language or social status.

To ensure nation wide library coordination and cooperation, legislation and strategic plans must also define and promote a national library network based on agreed standards of service.

The public library network must be designed in relation to national, regional, research and special libraries as well as libraries in schools, colleges and universities.

Services have to be physically accessible to all members of the community. This requires well situated library buildings, good reading and study facilities, as well as relevant technologies and sufficient opening hours convenient to the users. It equally implies outreach services for those unable to visit the library.

The library services must be adapted to the different needs of communities in rural and urban areas.'

(IFLA/UNESCO Public Library Manifesto, 1994)

\subsection{Introduction}

To be successful in fulfilling its goals the public library service must be fully accessible to all its customers. Customer is the term used primarily throughout the Guidelines (just as user, patron or client might be) to optimise consideration of public library non-users as potential customers. Also implicit in the term customer, individuals have expressed wants and needs to be identifed and met.

Customers ultimately have the choice of participating in public library service offered - or not. Therefore, any limitation of access, whether 
deliberate or accidental, will reduce the ability of the public library to fully achieve its primary mission and role of meeting the library and information needs of the community served. The following are important elements in delivering an effective public library service:

- identifying potential customers

- analysing customers' needs

- developing services to groups and individuals

- introducing customer care policies

- promoting library use education

- co-operating and sharing resources

- developing electronic networks

- ensuring access to services

- providing library buildings.

\subsection{Identifying potential customers}

The public library has to aim to serve all citizens and groups. An individual is never too young or too old to use a library onsite or online.

The public library has the following potential customer groups.

- People at all ages and at all stages of life:

- children

- young adults

- adults

- elderly

- Individuals and groups of people with special needs:

- people from different cultures and ethnic groups including indigenous people

- people with disabilities, e.g., physical, blind and partially sighted, hearing impaired

- housebound people

- institutionally confined people, e.g., in hospitals, prisons

- people lacking knowledge of library services

- Institutions within the wider community network:

- educational, cultural and voluntary organisations and groups in the community

- the business community

- the governing body of the parent organisation, e.g., local authority. 
As resources are limited in even the wealthiest society it is not always possible to serve all customers to the same level. The library must establish priorities based on an analysis of actual and potential customer needs and related to their access to alternative services.

\subsection{Analysing needs within the community}

It is important to establish who uses and who does not use the library service. It is also necessary to collect and analyse data that identifies those needs of individuals and groups within the community that can be met by the public library. (see chapter 6.10 'Management tools').

\subsection{Services to customers}

The public library must provide services based on an analysis of the library and information needs of the local community. In planning services, clear priorities must be established and a strategy be developed for service provision in the medium to long term. Services should be developed for identified target groups and only provided if such groups exist in the local community.

The services of the library should not be subject to any form of ideological, political, religious or commercial pressure. Services must be able to adjust and develop to reflect changes in society, for example, variations in family structures, employment patterns, demographic changes, cultural diversity and methods of communication. They should take account of traditional cultures as well as new technologies, for example, support for oral methods of communication as well as making use of information and communication technology. In some countries the services that the public library must provide are defined in library legislation.

\subsubsection{Service provision}

Public libraries provide a range of services, both within and delivered from the library, and in the community, to satisfy customers' needs. The library should facilitate access to its services for all, including those who have difficulty accessing services due to physical or mental disabilities. The following services should be as easily accessible as possible to the customers through a variety of formats, media, and via the Internet including: 
- loan of books and other media

- provision of books and other materials for use in the library

- information services using print and electronic media

- readers' advisory services including reservation services

- community information services

- library use education including support for literacy programmes

- programming and events

- modern communication tools such as blogs, cell phone messaging, and social networking tools used for both reference services and public relations.

This is not an exhaustive list but an indication of some of the key services of the public library. The range and depth of provision will depend on the size of the library and the community it serves. Every library should aim to be an active participant in one or more networks, which will give the customer access to a wide range of materials and services, however small the access point. Service provision should not be confined to the library building but also taken directly to the customer where access to the library is not possible. In providing services, both within the library and beyond, use should be made of information and communications technology as well as the printed word. A list of some of the resources the library should provide is detailed in Paragraph 4.3.1.

\subsubsection{Services to children}

By providing a wide range of materials and activities, public libraries provide an opportunity for children to experience the enjoyment of reading and the excitement of discovering knowledge and works of the imagination. Children and their parents should be taught how to make the best use of a library and how to develop skills in the use of printed and electronic media.

Public libraries have a special responsibility to support the process of learning to read, and to promote books and other media for children. Research indicates that if children do not develop the reading and library habit as a child, this will be unlikely to emerge as an adult. The library then must provide outreach, special events for children, such as storytelling and activities related to the library's services and resources. And children should be encouraged to read, develop information literacy skills, and use the library from an early age. In multilingual countries books and multimedia for children should be available in their mother tongue. 
- In France, some public libraries are co-operating with Health Services for Children to organise programmes for parents and their children while they are waiting for medical consultation. These are aimed at children aged birth to 3 years old, encouraging parents to read aloud to their children and visit the public library.

- In Bucharest, Romania, the city library offers summer programmes, run by volunteers, aimed at children aged 11 to 14 whose parents are at work.

- In the Netherlands, groups of people over age 50 were trained by the public library to read to children in schools, kindergarten and child care centres.

- In the State of Queensland, Australia, a range of activities for children is provided by the public library, including sessions for under fives, their parents and caregivers, storytelling, class visits, library orientation, reading groups, Internet training and homework clubs.

- The library service in Johnson County, Kansas, USA, provided 'Books to Grow' kits for pre-school through to first grade. Each kit has a theme and contains five books, one audio tape, one video tape and one activity folder.

- In Singapore, 41 childrens libraries for children under age 10 were established in co-operation with a local grassroots organisation, with collections of 10,000 items, full Internet services and a story-telling room. The funding came from the Library Board and the local organisation.

- Many libraries in the Nordic countries offer an incentive to visit the library by giving a gift book to parents and children on their first visit to the maternal and child health centre.

- "Ten Commandments for the future children's library" is a new report offering recommendations and suggestions for library services to children in Denmark. <http://splq.info/issues/vol41_3/04.htm>

- The "Young people's dream library" report indicates the young in Denmark desire a library which accepts them as they are. This dream library is also well-planned and easily accessible. Young people hope librarians will accept their youthful behaviour, and be within reach when they need assistance. <http://splq.info/issues/vol40_1/04.htm>

- The Centralised System of Municipal Libraries in Omsk, Russia implemented the cultural-educational project "World of Books for Kids," with the goal of enhancing a positive attitude to- 
wards reading amongst pre-schoolers, their parents, caregivers, and pre-school educational institutions.

<http://www.lib.omsk.ru/csmb.php?page=pp33>

- Central City Children's Library of A.P. Gaydar, Moscow, offers information to parents of, and children with, disabilities.

<http://www.gaidarovka.ru/index.php?option=com_content\& task=category\&sectionid=6\&id=87\&ltemid=292>

\subsubsection{Services for young adults}

Young people between childhood and adulthood develop as individual members of society with their own culture. Public libraries must understand their needs and provide services to meet them. Materials, including access to electronic information resources, that reflect their interests and culture should be provided. In some cases this will mean acquiring materials that represent youth culture, in a variety of media that are not traditionally part of a library's resources, for example, popular novels, book and television series, music, DVDs, teenage magazines, posters, computer games, and graphic novels. It is important to enlist the help of young people in selecting this material to ensure that it reflects their interests. In larger libraries this material, with appropriate furniture, can form a special section of the library. This will help them to feel that the library is for them and help to overcome a feeling of alienation from the library, which is not unusual among this age group. Relevant programmes and talks to young adults should also be provided (see IFLA Guidelines for Library Services for Young Adults).

- In Hamburg, Germany, young adults help to select and buy media stock for the young adults' library in a project called EXIT. The selections reflect their cultural background. The youth organised and gained sponsorship for their own Internet café. <http://www. buecherhallen.de>

- In Queensland, Australia, public library staff receive specialist training in working with young adults. The training covers customer care, programming ideas and how to run teenage advisory groups and homework clubs. In conjunction with local teenagers, many libraries have developed youth spaces.

- In Singapore a library aimed at people aged 18-35 has been established in the heart of the shopping area. Focus groups helped to define the profile of the collection and design the library. 
- In the USA, the Standards for Public Library Services to Young Adults in Massachusetts (MA)

<http://www.masslib.org/yss/REVISIONFeb051.pdf> advises providing reference services for homework assistance, personal, career and college information - using telephone and online referral. Reference librarians at the Haverhill Public Library in MA use instant messaging, texting, calling, and emailing to better communicate with youth. <http://www.haverhillpl.org/Services/askalibrarian.html>

\subsubsection{Services for adults}

Adults will have different requirements of an information and library service related to the variety of situations they will encounter in their studies, employment and personal life. These requirements should be analysed and services be developed on the outcome of that analysis. They should include support for:

- lifelong learning

- leisure time interests

- information needs

- community activities

- cultural activity

- recreational reading.

Services meeting these needs should also be available to children and young adults.

\subsubsection{Lifelong learning}

The public library supports lifelong learning, working with schools and other educational institutions to help students of all ages with their formal education. The challenge of providing educational support provides an opportunity for public libraries to interact and network with teachers and others involved in education. The public library should also provide a range of materials on a variety of topics which will allow people to follow their interests and support their formal and informal education. It should also provide materials to support literacy and the development of basic life skills. In addition the library must provide study facilities for students who have inadequate or no access to these facilities in their homes. 
The expansion of distance learning is having an impact on the public library. Distance learners, studying at home, are likely to make use of their local library as their primary source for material. Many will require access to the Internet which the public library should provide. Public libraries play an increasingly important role within the educational network and should provide space and access to materials to meet this demand.

- South Dublin County Library Service, Ireland, provides selflearning facilities for adults, including computer-based learning and audio and video-based language-learning materials. The aim is to provide a neutral and supportive environment in which individuals can learn at their own pace.

- Two libraries in Oklahoma, USA, sponsor discussion groups for new adult readers with grants from the National Endowment for the Humanities. The group reads one book at a time, usually a classic, and then discusses it with the help of a group facilitator.

\subsubsection{Leisure time interests}

People need information to support their leisure time interests, and meeting this need by a range of resources in a variety of formats is another key role of the public library. Public libraries must be aware of the cultural, social and economic changes in the community and develop services that are sufficiently flexible to adjust to these changes. The public library should also help to preserve the culture, history and traditions of the local community and make these readily available.

The public library, by organizing activities and exploiting its resources, should encourage artistic and cultural development in people of all ages. The library is also an important social centre for individuals and groups to meet both formally and informally. This is of special importance in communities where other meeting places are not available.

\subsubsection{Information services}

The rapid development of information technology has brought a vast amount of information within reach of all those with access to electronic media. Information provision has always been a key role of the public library and the ways in which information can be collected, ac- 
cessed and presented have changed radically in recent years. The public library has a number of roles in providing information:

- providing access to information at all levels

- collecting information about the local community and making it readily accessible, often in co-operation with other organisations

- training people of all ages in the use of information and the associated technology

- guiding customers to the appropriate information sources

- providing opportunities for disabled people to have independent access to information

- acting as a gateway to the information world by making it accessible to all, thus helping to bridge the gap between 'the information rich' and 'the information poor'.

The dramatic development of the Internet has been largely unstructured and uncontrolled. The vast amount of information that can be accessed via the Internet is of variable quality and accuracy and a key role of the librarian is to guide customers to accurate information sources, which will meet their requirements.

- In Horsens, Denmark, the library staffs an information booth supplying governmental, regional and local information, directing people to the right public department, and offering help with completion of government forms. Consumer questions are also answered. Both printed material and the Internet are used to deal with enquiries.

<http://www.bibliotek.horsens.dk>

- The Comfenalco Public Library in Medellin, Colombia, offers a website with up-to-date information about the city, including institutions, personalities, cultural events and procedures related to public services. It also publishes a series of guides on questions most frequently asked by customers.

<http://www.comfenalcoantioquia.com/sil>

- Libraries and Borger.dk (translated: Citizen.dk) is a national campaign promoted by Denmark's public libraries which encourages the public to access an established Internet portal. The website is designed to help people better manage their personal communications with public authorities.

<http://splq.info/issues/vol42_3/07.htm.> 


\subsubsection{Services to community groups}

The public library should be at the centre of the community if it is to play a full part in its activities. It should, therefore, work with other groups and organisations in the community. This will include departments of government and local government, the business community and voluntary organisations. An analysis of the information needs of these bodies should be conducted, and services be provided to meet these needs. This will not only help the organisations involved but will also demonstrate, in a practical way, the value of the public library to people in the community who are likely to have some influence on the future of the library service. Many public libraries, for example, provide an information service to local government politicians and staff, giving a practical demonstration of the value of the public library.

- Essex County Library, United Kingdom (UK), created websites for voluntary organisations. The library makes a small charge for this service at below the commercial level.

- Grant funds were used in Arizona, USA, to provide a computer lab in the library for use by children and adults from the Hualapai tribe.

- In the West Midlands region of United Kingdom (UK), a project (INTER-ALL) supported by funding from the European Regional Development Fund provides information to small businesses. Learning and information centres are being established in 13 libraries in the region, supported by 15 full-time positions.

\subsubsection{Services to special customer groups}

Potential customers who, for whatever reason, are unable to use the regular services of the library have a right to equal access to library services. In the United Kingdom, all libraries must comply with the Disability Discrimination Act and in the United States, the Americans with Disabilities Act. The library should in all cases strive to establish ways of making library material and services accessible to these customers. Library managers should be familiar with local ordinances to be in compliance. These will include:

- $\quad$ special transport, e.g., mobile libraries, book-boats and other forms of transport to serve those living in isolated areas

- services taken to the home of those people who are housebound 
- services taken to factories and industrial premises for employees

- services for those confined in institutions, e.g., prisons and hospitals

- special equipment and reading materials for those with physical and sensory disabilities, e.g., hearing impaired and visually impaired people

- $\quad$ special materials for people with learning difficulties, e.g., easy-toread materials and multimedia

- services for immigrants and new citizens to help them to find their way within a different society and to provide access to media of their native culture

- electronic communication, e.g., the Internet, electronic databases and other online resources.

Services for people with special needs can be enhanced by the use of new technology, for example, speech synthesizers for the visually impaired, online access catalogues for those in isolated areas or unable to leave their home, and connections to remote sites for distance learning. Mainstream service provision, for example, online public access catalogues (OPACs) can often be adapted to meet the needs of those with physical and sensory disabilities. Those who can benefit the most from technological developments are often the least able to afford the investment needed. Innovative schemes should, therefore, be developed by the public library to exploit the new technology in order to make services available to as many people as possible.

Services for ethnic groups in the community and for indigenous peoples should be developed in consultation with the group concerned. They are likely to include:

- the employment of staff from the group in the library

- collections including the native literature of the group and reflecting the oral tradition and non-written knowledge of the people

- the application of special conditions, developed in conjunction with local people, to culturally sensitive material.

- The Information Centre at Odense University Hospital is one of the oldest patient libraries in Denmark. The centre offers unique multi-disciplinary services for patients and relatives as well as information on health and specific illnesses. <http://www.ifla.org/files/Isn/newsletters/66.pdf>

- Denmark's Integration Exploratory for Ethnic Minorities focuses on library services for these populations, incorporating 
theories of "empowerment and new audience development" in order to implement new library services and improve existing ones.

<http://www.odense.dk/web/eksperimentarium/english.aspx>

- The section entitled "Mercy" on the website of the Central Public Library of Novouralsk, Russia, is a collection of information and best practices of libraries and various other organisations serving persons with disabilities.

<http://www.publiclibrary.ru/readers/mercy/about.htm>

- The Oslo Public Library in Norway maintains a tailor made web-service for language minorities in 14 languages. It contains information about libraries, culture, Norwegian society, how to learn the Norwegian language and identifies organisations for ethnic minorities. <http://bazar.deichman.no/>

- Public libraries in Croatia carry out literacy and reading programmes such as bibliotherapy and logobibliotherapy (preparing more easily read materials) for people with disabilities.

\subsubsection{The library in the community}

Library services are not bound by the walls of the library. Services can be provided or accessed in key locations throughout the community. Providing services where people congregate enables the library to connect with those who cannot easily visit the library.

- Library services have been provided at Metro stations in Santiago, Chile.

- Beach libraries serve vacationers in Catalonia, Spain and in Portugal during the summer months.

- Many forms of transport are used to deliver library services. Bookmobiles are common in many countries. There are book boats in Norway and Indonesia, where bicycles and pedicabs are also used. Donkeys in Peru transported laptop computers as well as books, camels were utillzed in Kenya and donkeycarts in Ethiopia. Mopeds are used to deliver books to the home or office in Apeldoorn, Netherlands.

- In parts of South Africa library services have been supplied to informal settlements or squatter areas with no infrastructure. This is done in a variety of ways, for example, from car boots, steel cabinets in clinics, cargo containers, under a tree or pro- 
vided by individuals or shops to other members of the community. Block loans are sometimes provided to schools and old people's homes. Storytelling and school project information is sometimes available at after-care centres for children unable to go the library.

- In Colombia, steel cabinets containing about 300 books, a bench and a space for a billboard were provided in places where people congregate. They opened for about two hours a day.

- In Manassas, VA, USA, a mall store-front housed the state's first electronic library. It offered (free to county residents) no books but rather computing and technology courses and virtual library services.

\subsubsection{Reading promotion and literacy}

Reading, writing and the ability to use numbers are basic prerequisites to being an integrated and active member of society. Reading and writing are also the basic techniques needed for making use of new communication systems. The public library should support activities that will enable people to make the best use of modern technology. It should support other institutions that are combating illiteracy and promoting media competence. It can achieve this by:

- promoting reading

- providing appropriate materials for those with poor literacy skills

- working with other agencies in the community involved in combating illiteracy

- participating in campaigns to combat illiteracy and improve numeracy

- organising events to promote an interest in reading, literature and media culture

- promoting and providing training in the use of computer technology

- promoting awareness of new developments in the media market

- helping people to find the information they need in the appropriate format

- co-operating with teachers, parents and other contact persons to help new citizens acquire the necessary educational skills that will help them to manage their lives in the new context.

The public library provides a range of creative literature and can use promotional techniques to bring its variety and range to the attention of its customers. It can also organise interactive programmes that enable customers to exchange views about books that they have read. 
- An interactive programme developed in Wandsworth, England, uses multimedia software to encourage readers to experiment with their reading and engage in dialogue about books they have read.

- The Book Bites project developed by The Libraries of Copenhagen, Denmark, in cooperation with a number of publishers, sends out a section of a novel via e-mail to approximately 1000 subscribers, so that after one week, each has received the entire first chapter.

<http://www.bibliotek.kk.dk/bibliotekerne/biblioteksudvikling /projekter/projekt- bogbidder-til-alle>

- Offaly and Limerick County Libraries, Ireland, in partnership with literacy students, tutors, local literacy organisers and the National Adult Literacy Agency, are active agents in literacy provision. They make a wide range of books and other materials available to adult literacy students and their tutors and generally promote a reading culture.

- In Singapore, the library works with a self-help group, training women who are learning English. Classes are held in the libraries, which support the programme by providing the resources needed.

- Comfenalco library in Medellin, Colombia, has a weekly page in the main city newspaper that includes reviews and comments on books for children.

- The "Project Love of Reading" in Denmark, attempts to stimulate bilingual children's joy of reading, by inspiring them to select favourite books from different genres and levels of reading, while simultaneously offering library use instruction. This project also strives to position the library as an active participant in the local society and neighbourhood.

<http://www.bibliotek.kk.dk/bibliotekerne/biblioteksudvikling /projekter/projekt-leselyst>

\subsubsection{Information literacy}

The public library must help its customers develop information literacy, defined as those skills by which a person should be able to recognise when information is needed and have the ability to locate, evaluate, and use effectively the needed information. While pupils in school, students in college and professionals working in learning organisations may have access to a professional librarian with expertise to help them 
develop independence and self-direction in information seeking the vast majority of the population the public library may serve, does not. What they do have, are information needs and rapidly changing technologies. If they are more fortunate they have a reasonably staffed and funded public library to guide them.

The infosphere can overwhelm any information seeker. And so, public librarians, in the $21^{\text {st }}$ century realise they must do more.

- In Spain, the Ministry of Culture promotes a group of experts to work in the planning process for public libraries to improve the information literacy skills of the population.

<http://www.alfinred.org/>

- "Glasgow REAL Learning Centres" which are part of Glasgow Libraries have a new team in place named Learning Support Officers who staff the centres (including learning portfolios, ITC and the employability agenda). The project is the partnership between Glasgow Libraries and the Chamber of Commerce.

- The library staff of Mpumalanga and, by extension, rural South Africa were trained to enhance information literacy skills so that they "may improve their service delivery and raise the profile of the public library by enskilling library users."

- Access to resources on the World Wide Web have benefited public library customers around the world through access to computers and networked information facilitated by the generous provisions of the Bill and Melinda Gates Foundation.

- Birmingham (UK) Central Library Learning Centre is integrated into a public library providing access to both the physical and electronic library content resources for independent and collaborative lifelong learning.

- Christchurch (NZ) City Libraries provide access to 3 learning centres. These are 'learning spaces, services and technology that enable carrying out of group learning programmes and activities with a computer focus.

- In the Wuhan area, a Chinese public library launched readeroriented training in information knowledge and technology.

- Libraries across the globe are providing classes regarding Internet safety for children. The Tampa-Hillsborough County Public Library system in the USA uses the NetSmartz Kids programme to teach internet safety. < http://www.hcplc.org/hcplc/justkids/adults/internet.html> 
- A network of 25 libraries <http://smartinvesting.ala.org> is now making resources available to more than 8 million customers at libraries in the USA through Smart investing@your library. Many of these libraries use new ways to reach out to their customers, including YouTube, the virtual world of Second Life, and other social networking tools.

\subsection{Customer care}

The policies and procedures of the library should be based on the needs and convenience of the customers and not for the convenience of the organisation and its staff. Quality services can only be delivered if the library is sensitive to the needs of its customers and shapes its services to meet those needs. Satisfied customers are the best advocates of the library service.

The public library should have a positive policy of customer care. This means ensuring that in all policy planning, design of libraries and of systems, preparation of operational procedures and drafting of information and publicity material, a positive effect on the customer should be a prime objective. The following actions should be elements in a customer care policy.

Staff related:

- the image projected by all libraries must be neutral and objective

- staff should be courteous, friendly, respectful and helpful at all times

- there should be a regular programme of staff training in customer care

- all staff should receive basic awareness training on how to deal with people with disabilities or from ethnic minorities

- staff should have a friendly and informative telephone manner

- jargon should be avoided in all forms of communication, verbal and written

- all printed information about services should be available in appropriate alternative formats, e.g., large print, tape, CDs, digital formats; they should also be available in alternative languages

- methods of communication with the customers must be provided, e.g., billboards, bulletins, website

- customers should receive a response in the shortest possible time; letters and other forms of communication should be answered promptly and courteously. 
Services and facilities:

- library services should be properly planned, adequately prepared and reliable

- the design of the library should be as convenient and inviting as possible

- opening hours should be convenient for the majority of the customers

- library catalogues and websites should be available online so that the customer can access services from home and outside opening hours

- there should be efficient renewal and reservation services including remote access services such as 24 hour telephone or online access

- services should be delivered beyond the library building when customers' needs require it

- equipment should be provided to make library use convenient, e.g., drop-in boxes for returning materials out of hours, self-service issue and return equipment in the library, answering machines, email and voice mail for communicating with the library out of hours

- good quality electronic equipment should be provided in the library including special equipment for the visually and hearing impaired.

\subsubsection{Customer participation}

Customers should be involved in service development:

- by asking them through surveys what services they use and require

- by analysing and responding to customers' complaints

- by monitoring customers' reactions to services and new initiatives

- by ensuring the input received from customers is considered in the development of policy and procedures

- by providing feedback to customers about the effects of their input on service development

- by providing suggestion boxes and a complaints and commendations procedure

- by conducting Friends' and library customer focus groups

- by gathering information from potential customer groups not using the library 


\subsection{Customer education}

The public library should help its customers develop skills that will enable them to make the most effective use of the library's resources and services. Library staff must act as information navigators to help customers of all ages to make the most effective use of information and communications technology, and programmes of customer education should be developed. As new technologies become more commonly available, the role of the public library both in providing access to these technologies and in helping people learn how to make best use of them is of vital importance.

Guided tours of the library should take place regularly to introduce people to the library building and services and how to use its tools, for example, catalogues and technical equipment. These guided tours have to be carefully planned according to the needs of those taking part. Tours for groups should be organised in co-operation with the institution from which they come.

- Public libraries in Singapore provide orientation programmes for new and existing customers. Tours of the library are also organised for classes from schools and kindergartens. Information literacy programmes are provided at different levels to assist customers in their search for information.

- Ten libraries in New Jersey, USA, were given grants to create computer training centres. Grants supported the purchase of PCs and the presentation of computer training courses on a variety of topics.

- Danish public libraries are active co-players in national programmes which strive to improve citizens' information technology (IT) skills. This is a requirement in the Danish Library Act and supported by two partnership agreements with the National IT and Telecom Agency. <http://splq.info/issues/vol42_3/05.htm>

\subsection{Co-operation and resource sharing}

Overall service to the community is enhanced when libraries develop links for exchanging information, ideas, services and expertise. Such co-operation results in less duplication of service, a combining of resources for maximum effect, and an overall improvement in community services. In addition, individual community members may in 
some cases be of great assistance in helping the library to carry out special tasks or projects.

The library should facilitate access to other libraries' online catalogues through its own online catalogue/OPAC through links to trusted sites, e.g., regional library systems and the national library website.

- Litteratursiden.dk (translated: The Literature site) is a Danish libraries' website which informs the public of new and classic voices from the world of literature, and recommends good books to read. The project is produced and financed by "Foreningen Litteratursiden." < http://www.litteratursiden.dk/>

\subsubsection{Formal links}

The library should establish formal links with other organisations in the local community, for example, schools, cultural institutions such as museums, galleries and archives, literacy programmes, chambers of commerce or boards of trade. The links should be used to co-ordinate the resources and efforts of each partner and thereby jointly improve services to the community.

\subsubsection{Relations with schools}

One of the most important institutional relationships for a public library is that with the local schools and the education system in the service area. Types of linkages and/or forms of co-operation include:

- sharing resources

- sharing staff training

- jointly arranged authors' visits

- co-operative collection development

- co-operative programming

- co-ordination of electronic services and networks

- co-operation in the development of learning tools

- class visits to the public library

- joint reading and literacy promotion

- programme of web-awareness for children

- sharing of telecommunications and network infrastructures.

(See IFLA/UNESCO School Library Manifesto) 


\subsubsection{Resource sharing}

Each library collection is in some degree unique. No collection can contain all the materials that the members of its public require. Libraries, therefore, can greatly enhance services to their users by providing them with access to the collections of other libraries. Libraries can participate in resource-sharing schemes at any level, local, regional, national and international.

The library should also make its collection available for loan to other libraries through participation in a network, for example, in a union catalogue or in a local network of information providers, such as schools, colleges and universities.

\subsubsection{Bibliographic records}

The library should classify and catalogue its resources according to accepted international or national bibliographic standards. This facilitates their inclusion in wider networks.

\subsubsection{Borrowing from other libraries}

In order to meet the information needs of customers the library should borrow materials from other libraries both within the same organisation and beyond. The library should establish interlending policies, which address such issues as:

- lending materials to other public libraries

- the type of materials it is prepared to lend or not to lend

- the length of time for which materials will be lent

- when it will request materials from other libraries

- methods of shipment

- how the costs of the service will be met

- action to be taken if materials are lost or damaged.

\subsection{Electronic networks}

Public libraries are instruments of equal opportunity and must provide a safety-net against alienation and social exclusion from technological advance by becoming the electronic doorway to information in the digital age. They should enable all citizens to have access to the information that will enable them to manage their lives at the local level, to acquire essential information about the democratic process and to participate positively in an increasingly global society. 
The library should provide access to the resources of the library and to those of other libraries and information services through the creation and maintenance of and participation in effective electronic networks at all levels from local to international. This can include participation in community networks, programmes to develop technologically advanced communities and electronic networks linking two or more agencies. They should also be part of national information policies.

- A virtual public library has been introduced in Denmark. It is now possible to gain access to the catalogues of all public libraries plus the larger research and special libraries. People can order an item from anywhere in the country and collect it at their local library. <http://www.bibliotek.dk>

- In the UK, many libraries participate in the Enquire service, an electronic reference service which is online 24 hours a day, 365 days of the year with the assistance of librarians internationally. Requests for information are sent online and automatically re-routed to the service. The library then responds directly to the enquirer.

- Net libraries of Denmark, provides an overview of a number of services directed towards library customers looking for knowledge and information on the internet.

<http://bibliotek.dk/netbib.php>

- The main objective of the project "Establishment and development of all-Russia Virtual Reference Service of Public Libraries" is to optimize the systems of reference and information services for customers of public libraries within the emerging information society with the goal of facilitating socio-political and economic change.

<http://www.library.ru/help/>

\subsubsection{Customer access}

The library should provide free public access to the Internet/World Wide Web to enable all citizens, regardless of economic means, to have access to information available in electronic form. It should have at least one public-access workstation with Internet access and a printer that is not shared with staff. 


\subsubsection{Remote access}

The library should exploit ITC to enable the public to gain access to as many of its electronic resources and services as possible from their home, school or workplace. If possible they should be made accessible 24 hours a day, seven days a week. Making library services available on the Internet increases their accessibility to the public, and to other libraries, and improves the quality of the service.

- DelAWARE, developed by Delaware State Library, USA, gives all Delaware citizens access to library information services and the Internet, regardless of geographic location or economic circumstances. It provides a variety of statewide online products and services, state government information, a subject guide to selected Internet sites and links to all types of Delaware libraries.

<http://www.lib.de.us>

- Via netmusik.dk, Danish libraries offer access to over 2 million songs and pieces of music, with continuous additions. The music is downloaded directly to the user's PC as a loan, for free. Most Danish public libraries are connected to Netmusik. dk.

<http://netmusik.shop2download.com/cgi-bin/WebObjects/ TShop.woa/wa/default>

- Netlydbog.dk (translated: NetAudiobook.dk) is the promotion of audio books online via the Internet in Denmark, in response to the growing demand for digital content on the Internet.

<http://www.netlydbog.dk/>

\subsubsection{Staff access}

Library staff should have access to the Internet/World Wide Web to enable them to provide better reference and readers' advisory service to customers. Staff should have regular training in using the Internet.

\subsubsection{Information navigator}

The public library's role is becoming one of mediator, of being the public's electronic doorway to digital information and of helping citi- 
zens cross the 'digital divide' to a better future. The librarian's role is increasingly one of 'information navigator' ensuring that the customer gets accurate and reliable information.

\subsection{Access to services}

Physical accessibility is one of the major keys to the successful delivery of public library services. Services of high quality are of no value to those who are unable to access them. Access to services should be structured in a way that maximises convenience to customers and potential customers.

\subsubsection{Location of service outlets}

Public library service outlets should be located for the maximum use and convenience of people in the community. Libraries should be near the centre of transport networks and close to areas of community activity, for example, shops, commercial centres, and cultural centres. Where appropriate the public library may share buildings with other services such as arts centres, museums, art galleries, community centres and sports facilities. This can help to attract customers and achieve capital and operational economies.

The outlet should be highly visible and easily reached by foot, public transport, where available, or by private vehicle and in this instance provide convenient parking. In well-developed urban and suburban areas a public library should be available within a journey by private vehicle of about 15 minutes.

Issues of equity of access should be addressed when possible through strategic location of the outlet to reach potential customer groups who may lack any other information access than the public library or knowledge of its services. Outreach delivery may be a part of the solution (see sections 1.10 and 3.4.10).

- In Singapore, libraries are located in the town centres of government housing. Childrens' libraries are located on the ground floor of apartment blocks and are within five minutes' walk of most children in the neighbourhood. 


\subsubsection{Opening hours}

In order to provide the best possible access to library service, the library must be open at times of maximum convenience to those who live, work and study in the community. This access may extend into 24 hour maintenance of telephone or web access of select services.

\subsection{Library buildings}

In general when planning a library, the librarian and governing body should consider the following elements:

- the function of the library

- the size of the library

- designated spaces

- design features

- access for the physically handicapped

- signage

- the ambience of the library

- electronic and audiovisual equipment

- safety

- parking.

They should also ensure that the design incorporates flexibility in every aspect including furnishings to accommodate rapidly changing technology and demands for library services.

\subsubsection{The function of the library}

The library should have adequate space to implement the full range of library services that are consistent with the library's strategic plan and that meet local, area or national standards/guidelines. Libraries in England are asked to meet criteria to assure they meet their obliglations to the community served.

$<$ http://www.culture.gov.uk/Reference_library/Publications/archive _2007/library_standards.htm>

Some of these criteria include:

- proximity of libraries to their customers

- opening hours

- access to the Internet and other items purchased new each year

- number of books and other items purchased new each year 


\subsubsection{The size of the library}

The amount of floor-space required by a public library depends on such factors as the unique needs of the individual community, the functions of the library, the level of resources available, the size of the collection, the space available and the proximity of other libraries. Because these elements will vary significantly from country to country and between different building projects it is not possible to propose a universal standard on the space required for a public library. However local standards have been developed and examples from Ontario, Canada and Barcelona, Spain and Queensland, Australia are included in the appendices, and may be of use in the planning process.

\subsubsection{Designated spaces}

The library should include space for services to adults, children (including babies and toddlers) and young adults and for family use. It should aim to provide a range of materials to meet the needs of all groups and individuals in the community (see Chapter 4 'Collection development').

The range of functions provided and the space available for each will depend on the size of the library. In planning a new library the following should be considered for inclusion:

- the library collection, including, books, periodicals, special collections, sound recordings, film, and other non-print and digital resources

- reader seating space for adults, children and young adults to use for leisure reading, serious study, group work and one-one tutoring; quiet rooms should be provided

- outreach services: space should be provided to house special collections and preparation areas for outreach services, e.g., mobile library deposit areas.

- staff facilities, including work space (including desks or PC workstations), rest space for eating and relaxing during breaks and meeting rooms where staff can meet with colleagues and supervisors in private

- meeting room space for large and small community groups, which should have separate access to the washrooms and to the exterior to enable meetings to be held while the library is closed

- technology including public access workstations, printers, CDDVD drives, printers, copiers, scanners, webcams, microfilm/fiche readers 
- special equipment, including atlas cases, newspaper racks, selfservice book circulation, dictionary stands, wall-mounted display racks, display stands, filing cabinets, map cases etc.

- sufficient space for ease of circulation by both public and staff; this can be $15 \%-20 \%$ of public areas and $20 \%-25 \%$ in staff areas, and allow for at least the minimum access requirements for wheelchair customers

- in larger libraries a café area for the public is a desirable facility or vending machines in smaller libraries

- space must be allowed for the mechanical services of the library, e.g., elevators, heating, ventilation, maintenance, storage of cleaning materials, etc.

\subsubsection{Design features}

The library should guarantee easy access for all customers and in particular persons with physical and sensory disabilities. The following features should be included in the planning of a new library:

- the exterior of the library should be well lit and identified with signs clearly visible from the street

- the entrance of the library should be clearly visible and located on that part of the building that most users approach.

- the library should focus on eliminating barriers to use

- there should be no design features that limit the ability of an individual or groups to use any part of the library

- care should be taken to avoid steps as much as possible in both interior and exterior design and alternative access provided where use cannot be avoided in the design.

- lighting levels should comply with those stated in international or national standards

- libraries that occupy two or more floors should provide elevators that are close to the library entrance and that easily accommodate wheelchairs and child strollers

- the library should provide facilities for the return of library materials when the library is closed; after-hours deposit boxes should be both theft and waterproof

- a library should undertake an 'accessibility' audit on a regular basis to confirm that there are no barriers to easy use

- local, national or international standards on making public buildings accessible to the disabled should be followed, wherever possible. 


\subsubsection{Accessible shelving}

Materials should be displayed on open shelves and arranged at a height within easy reach for customers and steps and mobile seats provided for any people not able to reach or bend to the levels of the high and low shelves. All shelving should be adjustable and preferably on lockable wheels so that it can easily be moved. The furniture in the children's section should be appropriately sized. Shelves should be of accessible height and width for persons with disabilities.

\subsubsection{Signage}

The library's exterior signs not only identify the particular function of the building but are also the library's most basic form of publicity. Signs should therefore be carefully planned to communicate an appropriate image of the library. Internal areas of the library and parts of the collection should be clearly identified by signs of a professional standard so that customers can easily find them, for example, the library catalogue, magazines, reference services, the children's area, washrooms, Internet stations, copy machines etc. Signs should also be posted in Braille where necessary. Where appropriate, signs should be provided in languages used by ethnic groups in the community. A sign displaying the opening hours of the library should be clearly visible from outside the library. Talking kiosks, web or audio guides should also be considered to help all customers find their way in the library. Directional signs should be erected in nearby streets and town centres to guide the public to the library and referral from all relevant local web sites assured.

\subsubsection{The ambience of the library}

The library should provide a physical setting for the library service that is inviting to the public and that provides:

- adequate space to store and display the library collection

- adequate, comfortable and attractive space for the public to make proper and convenient use of the library's services

- adequate quiet space for study and reading

- meeting spaces for groups of various sizes

- sufficient space for the library staff to carry out their duties in an efficient and comfortable setting

- toys and play facilities might be provided in children's areas 
- young adult sections could include facilties for computer gaming, "chill out" zones with comfortable seating, and TV or plasma screens

- adequate space and flexibility for the future.

The climate of the library should be maintained at a comfortable temperature, using efficient heating and air conditioning. Humidity control helps to protect the stock as well as increasing the comfort of the library.

Larger libraries may include a café (and smaller libraries vending machines) open either throughout the opening hours of the library or for special occasions. Such facilities are sometimes contracted out to a commercial provider.

- In the UK "Ideas Stores" introduced in Tower Hamlets Library Service, London, include cafes as a part of the new interpretation of library service. <http://www.ideastore.co.uk/>

- In Singapore, the concept of 'lifestyle' libraries is being introduced. These include cafés, music listening-posts, and a virtual community for students. All libraries are open seven days a week.

\subsubsection{Electronic and audiovisual equipment}

A major function of the public library is to bridge the gap between the information rich and the information poor. This includes providing access to the necessary electronic, computer and audiovisual equipment such as personal computers with Internet access, public access catalogues, microform readers, audio and MP3 players, tape recorders, slide projectors and equipment for the visually and physically handicapped. Wireless (wi-fi) access is advisable throughout the library as well as access to electrical outlets for use of personal computers. Wiring should be up-to-date and easily accessible for alterations at a later date. It should also be inspected regularly.

\subsubsection{Safety}

Every effort should be made to ensure that the library is safe for the public and the staff. Smoke and fire alarms should be provided and security protection for staff and resources. The location of fire extin- 
guishers and emergency exits should be clearly marked. Staff should be trained in first aid and first aid supplies be made readily available. Evacuation drills should be carried out regularly. The library manager in co-operation with the emergency services should prepare a disaster plan to be put into action in the event of a serious incident, for example fire.

\subsubsection{Parking}

Where customers travel to the library in private vehicles there should be sufficient safe and well lit parking either at or close to the library with appropriately identified spaces for persons with disabilities. If bicycles are a common mode of transport, secure cycle racks should be provided outside the library.

\section{Resources}

Bill \& Melinda Gates Foundation (2004). Toward Equality of Access: The Role of Public Libraries in Addressing the Digital Divide. Seattle: The Foundation. Available at (http://www.imls.gov/pdf/Equality.pdf)

Cylke, F., Byrne, W., Fiddler, H., Zharkov, S.S., and IFLA Section of Libraries for the Blind, Standards Development Committee. (1983). Approved recommendations on working out national standards of library services for the blind, available (http://www.nplg.gov.ge/dlibrary/collect/0001/000561/IFLA.pdf)

Note: now called 'Section of Libraries Serving Persons with Print Disabilities' see Kavanaugh reference in this resource list.

Day, J.M., and IFLA Section for Libraries Serving Disadvantaged Persons. (2000). Guidelines for library services to deaf people, $2^{\text {nd }}$ ed., Professional report \#62. The Hague: IFLA.

de Jager, K., Nassimbeni, M. ( 2007). Information Literacy in Practice: engaging public library workers in rural South Africa. IFLA Journal, Vol. 33, No. 4, 313-322.

EBSCO Industries, Inc. (n.d.). EBSCO Publishing customer success center. (http://www.ebscohost.com/customerSuccess/default.php accessed 1/01/2010).

Fasick, A.. (2008). Managing children's services in the public library. Westport, CT: Libraries Unlimited.

IFLA. (n.d.) The IFLA/UNESCO Multicultural Library Manifesto. (http://www.ifla.org/en/publications/the-iflaunesco-multicultural-library-mani festo

accessed 1/01/2010). 
IFLA Children's and Young Adults Section. (2007). The Guidelines for Library Services to Babies and Toddlers. The Hague: IFLA.

(http://archive.ifla.org/VII/d3/pub/Profrep100.pdf accessed 1/01/2010).

IFLA Libraries for Children and Young Adults Section. (2003). Guidelines for Children's Libraries Services. The Hague: IFLA.

(http://www.ifla.org/en/publications/guidelines-for-childrens-library-services accessed 1/01/2010).

IFLA Section for Public Libraries. (2003). The Role of Libraries in Lifelong Learning. Final report of the IFLA project under the Section of Public Libraries (http://www.ifla.org/en/publications/the-role-of-libraries-in-lifelong-learning accessed 1/01/2010).

IFLA Public Libraries Section. (2008). Meeting User Needs: A checklist for best practice produced by section 8 - public libraries section of IFLA.

(http://www.ifla.org/VII/s8/proj/Mtg_UN-Checklist.pdf accessed 1/01/2010).

IFLA Section for Library Services to Multicultural Populations. (2009). Multicultural communities: guidelines for library services, $3^{\text {td }}$ ed. The Hague: IFLA.

(http://www.ifla.org/en/publications/multicultural-communities-guidelines-forlibrary-services-3rd-edition accessed 1/01/2010).

IFLA Section of School Libraries and Resource Centers. (2002). The IFLA/ UNESCO School Library Guidelines 2002.

(http://www.ifla.org/en/publications/the-iflaunesco-school-library-guidelines2002

accessed 1/01/2010).

Kavanaugh, R., Sköld, B.C., and IFLA Section of Libraries Serving Persons with Print Disabilities. (2005). Libraries for the blind in the information age: Guidelines for development. The Hague: IFLA.

(http:/ /www.ifla.org/en/publications/ifla-professional-reports-86 accessed 1/01/2010).

Lau, J. (2008). Information literacy: International perspectives. Munich: K.G. Saur (http://archive.ifla.org/V/pr/saur131.htm accessed 1/01/2010).

Li, J. (2002). The Public Library and citizens' information literacy education in China: a case study of Wuhan area, China. IFLA Conference Proceedings, 1-8. Retrieved from Library, Information Science \& Technology Abstracts database Lesk, M. (2005). Understanding digital libraries. Amsterdam: Elsevier.

McMenemy, D. and Poulter, A. (2005). Delivering digital services: A bandbook for public libraries and learning centres. London: Facet.

Melling, M., and Little, J. (2002). Building a successful customer-service culture: A guide for library and information managers. London: Facet.

Muller, P., Chew, I., and IFLA Section of Libraries for Children and Young Adults. (2008). Guidelines for Library Services for Young Adults The Hague: IFLA. 
(http://www.ifla.org/en/publications/revised-guidelines-for-library-services-foryoung-adults accessed 1/01/2010).

Lehmann, V., Locke, J., and IFLA Section for Libraries Serving Disadvantaged Persons. (2005). Guidelines for library services to prisoners, $3^{\text {rd }}$ ed. Professional report \#34. The Hague: IFLA.

(http:/ / archive.ifla.org/VII/s9/nd1/iflapr-92.pdf accessed 1/01/2010).

Mayo, D. (2005). Technology for results: Developing service-based plans. PLA results series. Chicago: American Library Association.

Nielsen, G. S., Irvall, B., and IFLA Section of Libraries for Disadvantaged Persons. (2001). Guidelines for library services to persons with dyslexia. The Hague: IFLA. (http://www.ifla.org/VIIs9/nd1/iflapr-70e.pdf accessed 1/01/2010).

Panella, N.M., and IFLA Section for Libraries Serving Disadvantaged Persons. (2000). Guidelines for libraries serving hospital patients and the elderly and disabled in longterm care facilities. Professional report \#61. The Hague: IFLA.

(http://archive.ifla.org/VII/s9/nd1/iflapr-61e.pdf accessed 1/01/2010).

Public Agenda Foundation. (2006). Long Overdue A Fresh Look at Public Attitudes About Libraries in the $21^{\text {st }}$ Century. New York: Public Agenda.

(http://www.publicagenda.org/files/pdf/Long_Overdue.pdf accessed 1/01/2010)

Reading Agency. (n.d.). The Reading Agency. (http://www.readingagency.org.uk/ accessed 1/01/2010).

Ross, C., McKechnie, L., and Rothbauer, P. (2006). Reading matters: What the research reveals about reading, libraries and community. Westport, CT: Libraries Unlimited.

Syracuse University College of Law. (n.d.). International and comparative disability law web resources.

(http://www.law.syr.edu/lawlibrary/electronic/humanrights.aspx accessed 1/01/2010)

UNESCO. (2006). UNESCO Launches a Community Information Literacy Project at the Tunapuna Public Library (2007) (http:/ / portal.unesco.org/en/ev.phpURL_ID=36505\&URL_DO=DO_TOPIC\&URL_SECTION=201.html)

Webster, K., and Biggs, B. (2005). Library services to indigenous populations: Viewpoints \& resources. Chicago: Office for Literacy and Outreach Services, American Library Association.

Weibel, M. (2007). Adult learners welcome here: A bandbook for librarians and literacy teachers. New York: Neal-Schuman Publishers. 
